\title{
Isolation and purification of developmental stages of Perkinsus karlssoni (Apicomplexa: Perkinsea), a parasite affecting bay scallops Argopecten irradians
}

\author{
S. K. Whyte, R. J. Cawthorn, R. J. MacMillan, B. Despres \\ Department of Pathology \& Microbiology, Atlantic Veterinary College, University of Prince Edward Island, \\ 550 University Avenue, Charlottetown, Prince Edward Island, Canada C1A 4P3
}

\begin{abstract}
Isolation and purification of the trophozoite and schizont stages of the protozoan Perkinsus karlssoni, a parasite affecting Argopecten irradians, was achieved by macerating infected host tissue. Prior culture of infected tissue in fluid thioglycollate medium was unnecessary either for detecting Perkinsus karlssoni in the host tissue, or for collecting developmental stages of the parasite for further studies. The maceration technique is rapid and simple to perform, yielding numerous viable trophozoites and schizonts which are relatively free of contaminating host material. Trophozoites and schizonts demonstrated good retention of structural integrity following isolation from host tissue. These stages were further purified by separation from host material using a Percoll gradient and were harvested at the 50 to $60 \%$ interface. Development of the successive parasite stages was observed to proceed in vitro when trophozoites and schizonts were transferred to petri dishes containing sterile seawater fortified with antibiotics and incubated at $26^{\circ} \mathrm{C}$. Light and electron microscopy were used to document the development of zoosporangia in vitro. The terminal stage of development was the release of biflagellate zoospores after $3 \mathrm{~d}$ at $26^{\circ} \mathrm{C}$. All stages of the parasite could be used for further studies including development of specific diagnostic aids.
\end{abstract}

\section{INTRODUCTION}

Parasitism by members of the apicomplexan family Perkinsidae (Levine 1978) can have deleterious effects on the molluscan hosts in which they have so far been described. Members of this family comprise: Perkinsus marinus (Mackin et al. 1950, Mackin 1951, Ray et al. 1953, Mackin \& Ray 1966, Andrews 1988, Crosby \& Roberts 1990), P. atlanticus (Azevedo 1989, 1990), P. olseni (Lester \& Davis 1981), P. karlssoni (McGladdery et al. 1991) and various unidentified Perkinsus spp. (Goggin \& Lester 1987, Perkins 1988). The majority of work cited in the literature to date has dealt with the interaction of $P$. marinus with its hosts and comprises descriptions of the organism and the pathology it causes, as well as the epidemiology of the clinical disease. Studies of $P$. karlssoni, $P$. atlanticus and $P$. olseni have however been limited, and particularly in the case of $P$. karlssoni, remain essentially descriptive (McGladdery et al. 1991).
Perkinsus karlssoni was named after being identified in tissues of bay scallops Argopecten irradians collected from 2 maritime shellfish hatcheries (Nova Scotia and Prince Edward Island, Canada) but had also been recorded in bay scallops from Rhode Island, Connecticut (Karlsson 1991) and Cape Cod, Massachusetts, USA (McGladdery et al. 1991). Recent observations on the occurrence of this parasite suggest a host specificity for bay scallops (McGladdery et al. 1991), although cross-transmission studies are currently ongoing in our laboratory. There is, however, continuing concern over the potential threat this parasite could pose to other bivalves economically important to the aquaculture industry of the Atlantic region.

All documented techniques for the isolation of endogenous and free-living stages of Perkinsus sp. have used tissue which has previously been cultured in fluid thioglycollate medium (FTM). Ray (1966) removed positive tissues from FTM and placed them into seawater. After a brief period (determined by tem- 
perature) zoospores were released. Perkins \& Menzel (1966) and later Chu \& Greene (1989) modified this technique by digesting infected tissue cultured in FTM with trypsin and purifying the 'prezoosporangia' by centrifugation. They reported that this enabled most contaminating host material to be removed. Trophozoites were cultured in seawater where they developed into zoosporangia and eventually released zoospores. Choi et al. (1989) were also able to isolate tissue-free trophozoites from host material cultured in FTM by treating the latter with $2 \mathrm{M} \mathrm{NaOH}$.

Isolation and purification of all lifecycle stages of the parasite is important when trying to elucidate the relationship of the parasite with its host at all levels; cellular, individual and population. Collection of parasitic material also enables the development of specific diagnostic tools for rapid diagnosis of the disease. This paper describes the techniques investigated for the isolation and purification of the different stages of Perkinsus karlssoni from the bay scallop.

\section{MATERIALS AND METHODS}

Laboratory maintenance of bay scallops. Infected bay scallops were collected directly from broodstock hatchery tanks at Nova Scotia and Prince Edward Island facilities. Infected scallops were transferred to the Atlantic Veterinary College, and maintained in a closed-circulation, artificial seawater (Instant Ocean), quarantine system. Water temperatures were kept at 22 to $25^{\circ} \mathrm{C}$ and salinities of 28 to $30 \%$. Scallops were fed daily with cultured algae (Chaetoceros gracilis and Tahitian isochrysis] and SDA [Spray Dried Algae (Tetraselmis), Cell Systems Ltd, Orwell House, Cowley Road, Cambridge CB4 4WY, UK]. Prior to entry into the quarantine facility, a sample (10\% of total number) from each batch of bay scallops was screened for the presence of Perkinsus karlssoni.

Fluid thioglycollate culture (Ray 1966). Bay scallop tissue (rectum, digestive gland, gill and mantle) was excised and cultured in fluid thioglycollate medium (Difco) containing chloramphenicol (Sigma) $(0.1 \mathrm{~g}$ $10 \mathrm{ml}^{-1}$ ) and nystatin (Sigma) (40000 USP units $\left.10 \mathrm{ml}^{-1}\right)$, for $5 \mathrm{~d}$ at room temperature $\left(20 \pm 2^{\circ} \mathrm{C}\right)$ (Howard \& Smith 1983). The tissue was then cut into $1 \mathrm{~cm}^{2}$ pieces and blotted dry on filter paper to remove excess thioglycollate medium. A sub-sample was examined microscopically, after staining with a $50 \%$ Lugol's iodine solution, to determine the level of perkinsus karlssoni infection.

Isolation of trophozoites and schizonts of Perkinsus karlssoni from host tissue. Group A: whole bay scallops: Tissues from whole bay scallops were incubated in FTM as described above. Individuals found to be positive after treatment with Lugol's iodine were placed into groups of 10 and processed according to one of the following procedures:

(1) placed whole in $9 \mathrm{~cm}$ diameter petri dishes containing sterile artificial seawater (SAS) (28 to $30 \%$ ) plus $200 \mathrm{U}$ penicillin $\mathrm{ml}^{-1}$ (Gibco), $200 \mu \mathrm{g}$ streptomycin $\mathrm{ml}^{-1}$ (Gibco) and $0.50 \mu \mathrm{g}$ Fungizone $\mathrm{ml}^{-1}$ (Gibco), and maintained in the dark at $26^{\circ} \mathrm{C}$.

(2) placed whole into a $0.25 \%(\mathrm{w} / \mathrm{v})$ solution of trypsin (Gibco) and incubated at room temperature for $4 \mathrm{~h}$ with continual stirring. The tissue was removed and macerated in a $7 \mathrm{ml}$ glass tissue grinder (Sigma).

(3) placed whole into a $0.5 \%(\mathrm{w} / \mathrm{v})$ pepsin $(\mathrm{BDH}$ Chemicals) solution and incubated at room temperaiure for $4 \mathrm{~h}$ with continual stirring. The tissue was removed and macerated with a $7 \mathrm{ml}$ glass tissue grinder.

(4) macerated in a $7 \mathrm{ml}$ glass tissue grinder.

Group B: macerated bay scallops: Tissue from groups of 10 whole bay scallops were macerated in a $7 \mathrm{ml}$ glass tissue grinder and either:

(1) cultured in FTM for 5 d.

(2) cultured in FTM for $5 \mathrm{~d}$. At the end of this period, the tissue was transferred to a $0.25 \%$ trypsin solution and incubated at room temperature for $4 \mathrm{~h}$ with continual stirring

(3) cultured in FTM for $5 \mathrm{~d}$. The tissue was then transferred to a $0.5 \%$ pepsin solution and incubated for $4 \mathrm{~h}$ at room temperature with continual stirring

(4) placed in SAS and maintained in the dark at $26^{\circ} \mathrm{C}$.

At the end of procedures (2), (3) and (4) of Group A and all of Group B, disrupted tissue was washed through a series of cell dissociation sieves (380 to 104 $\mu \mathrm{m})$. The filtrate was then placed into a petri dish with SAS plus penicillin/streptomycin and Fungizone ${ }^{\otimes}$ and maintained in the dark at $26{ }^{\circ} \mathrm{C}$. All groups were monitored daily for the development of zoosporangia and biflagellate zoospores.

Purification of trophozoites and schizonts. Trophozoites and schizonts of Perkinsus karlssoni isolated from infected bay scallop tissue were purified by centrifuging the tissue filtrate (obtained from the isolation procedure) at $1500 \times \mathrm{g}$ for $30 \mathrm{~min}$ at $6^{\circ} \mathrm{C}$, in a Beckman J2-21 M/E centrifuge. The pellet was resuspended in $10 \mathrm{ml} \mathrm{SAS} \mathrm{(28} \mathrm{to} 30 \%$ ) with $0.2 \%$ Tween 80 (J. T. Baker Chemical Co.) and spun again at $1500 \times g$ for $30 \mathrm{~min}$ at $6{ }^{\circ} \mathrm{C}$. The supernatant was aspirated off and the pellet resuspended in $10 \mathrm{ml}$ of SAS plus Tween. This was layered onto a $25 \%(\mathrm{w} / \mathrm{w})$ sucrose cushion and spun at $1500 \times g$ for $30 \mathrm{~min}$ at $6^{\circ} \mathrm{C}$. The pellet was resuspended in SAS plus Tween and centrifuged at $1500 \times g$ for $30 \mathrm{~min}$ at $6{ }^{\circ} \mathrm{C}$, to remove excess sucrose. The pellet was again resuspended in SAS plus Tween and layered onto a Percoll gradient $(10,20,30$, 
$40,50,60 \%$ ) which contained $0.5 \mathrm{M} \mathrm{NaCl}$ to prevent osmotic shock. This gradient was centrifuged as described above and the bands collected using Pasteur pipettes. Each fraction was examined microscopically to determine which level contained parasites. The relevant fraction was resuspended in SAS plus Tween and layered onto a $15 \%(\mathrm{w} / \mathrm{w})$ sucrose cushion and centrifuged as before. The pellet was resuspended in SAS plus $200 \mathrm{U}$ penicillin/200 $\mu \mathrm{g}$ streptomycin and $0.5 \mu \mathrm{g}$ Fungizone $\mathrm{ml}^{-1}$ and washed as before to remove excess sucrose. Finally the pellet was resuspended with SAS plus antibiotics, and cell identity and concentration determined using a haemocytometer

Electron microscopy. Material collected from the various groups was washed with SAS without antibiotics and centrifuged at $2000 \times g$ for $20 \mathrm{~min}$. The pellet was processed for transmission electron microscopy following the technique described by Azevedo (1990). Sections were viewed with a Hitachi 7000 operated at $75 \mathrm{kV}$.

\section{RESULTS}

The number of days required for zoospores to be released from zoosporangia, which were maintained in SAS at $26^{\circ} \mathrm{C}$, varied according to the isolation technique (Table 1). Maceration of bay scallop tissue either before or after culture in FTM, followed by digestion in either pepsin or trypsin, had no effect upon the time required for zoospore production in seawater. Digestion of tissue with trypsin or pepsin did not affect the viability of zoosporangia and zoospores were released. Fewer zoosporangia were obtained, however, compared to techniques which did not utilise the digestion process. Whole bay scallop tissue which was removed from the shell and incubated in SAS at $26^{\circ} \mathrm{C}$ resulted in diapedesis after $24 \mathrm{~h}$ and appearance of zoosporangia on the bottom of the petri dish after $48 \mathrm{~h}$. Zoospores were apparent $72 \mathrm{~h}$ after zoosporangia first appeared in the plate (Table 1). This technique, however, gave rise to a large amount of tissue debris and heavy bacterial contamination in the plates.

Maceration of bay scallop tissue followed by filtration prior to incubation in SAS resulted in zoospore production in the shortest time. The number of zoospores released after each extraction method varied according to the intensity of infection in the group of scallops used. Culture of trophozoites and schizonts in FTM did not result in greater numbers of zoospores from subsequent zoosporangia in SAS as compared to trophozoites and schizonts placed directly into SAS with no FTM culture.

Maceration of bay scallop tissue followed by filtration and incubation in SAS at $26^{\circ} \mathrm{C}$ provided zoospores after $3 \mathrm{~d}$. This proved to be the most efficient technique for the isolation of trophozoites and schizonts and the collection of zoosporangia and zoospores. Purified trophozoite and schizont stages were obtained following separation of host and parasite material on a Percoll gradient. Trophozoites and schizonts were observed at the 50 to $60 \%$ interface.

Zoosporangia of Perkinsus karlssoni maintained in SAS in vitro appeared spherical although variable in diameter and cell content. Some parasite cells were uninucleate with an eccentric nucleus and thick cell wall (Fig. 1a, b). Others appeared to comprise many individual cells contained within a single cell wall (Fig. 2a). Karyokinesis was occurring in some zoosporangia as evident by the presence of multiple nuclei (Fig. 2b). Development proceeded such that cytokinesis and bipartitioning of the cell resulted (Fig. 3a, b). Mature zoosporangia each developed a discharge tube (Fig. 4) through which they eventually released biflagellate, uninucleate zoospore stages. Following release of zoospores, empty zoosporangia were observed (Fig. 5).

\section{DISCUSSION}

The purpose of collecting developmental stages of Perkinsus karlssoni was 2-fold: firstly to observe the development of zoosporangia and zoospores in vitro and so, enhance interpretation of the lifecycle. Secondly, collection of host-free parasitic stages would provide material for development of specific diagnostic aids.

The current method for the routine diagnosis of all

Table 1. Perkinsus karlssoni. Extraction methods for trophozoites and schizonts and comparison of time required for zoospore production at $26^{\circ} \mathrm{C}$ in sterile artificial seawater (SAS). FTM: Fluid thioglycollate medium

\begin{tabular}{|lcc|}
\hline Tissue & Extraction method & Time (h) \\
\hline Whole bay scallops & Culture in FTM for 5 d & \\
& Macerate and digest in trypsin & 96 \\
& Macerate and digest in pepsin & 120 \\
& Macerate & 120 \\
& Transfer to seawater & $48-72$ \\
& Transfer to SAS & 120 \\
& & \\
Macerated bay & Culture in FTM for 5 d & 96 \\
scallops & Digest in trypsin & 120 \\
& Digest in pepsin & 72 \\
& Transfer to seawater & $48-72$ \\
& Transfer to SAS & \\
\hline
\end{tabular}



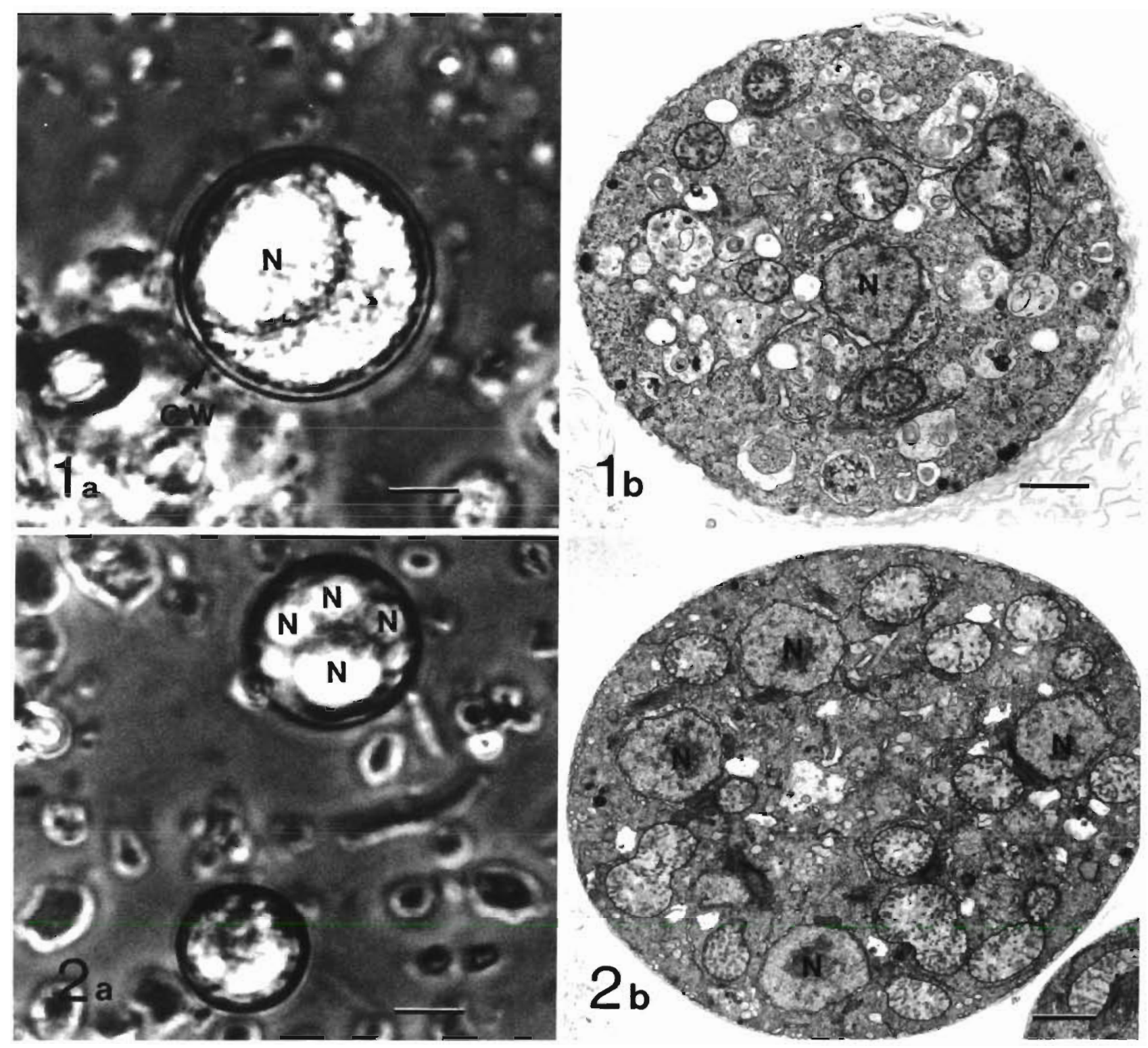

Figs. 1 \& 2. Perkinsus karlssoni. Photomicrographs and electron micrographs of developing zoosporangium in seawater. Fig. 1 (a) Photomicrograph of living uninucleate zoosporangium at the beginning of the zoosporulation process. The nucleus ( $N$ ) and thick cell wall (CW) are indicated. Scale bar $=28 \mu \mathrm{m}$. (b) Thin section of a similar uninucleate zoosporangium showing the nucleus (N). Scale bar $=3.5 \mu \mathrm{m}$. Fig. 2 (a) Photomicrograph of a dividing multinucleate $(N)$ zoosporangium in seawater. Scale bar $=42 \mu \mathrm{m}$.

(b) Thin section of a similar multinucleate zoosporangium with 4 nuclei $(\mathrm{N})$. Scale bar $=3 \mu \mathrm{m}$

known Perkinsus sp. has been culture of infected tissue in FTM fortified with antibiotics (Ray 1966, Lester \& Davis 1981, Azevedo 1989, McGladdery et al. 1991). Culture in FTM results in an enlargement of the trophozoite stage with massive spore development (Perkins \& Menzel 1967, Lester \& Davis 1981), thus facilitating observation by light microscopy following staining with an iodine solution. A semi-quantitative numerical scale was developed to assess the level of infection intensity based on the number of positively stained trophozoites apparent in suspect tissues (Ray et al. 1953, Craig et al. 1989). This technique has several advantages over histological examination when large amounts of material are to be processed and is used routinely for disease monitoring. There are, unfortunately, potential inaccuracies and misdiagnoses associated with the use of this technique and alternative methods for diagnosis have recently been suggested (Choi et al. 1989, Gauthier \& Fisher 1990). For example, Gauthier \& Fisher (1990) developed a haemolymph assay to determine the presence of the parasite within haemocytes. They claim this technique is more 

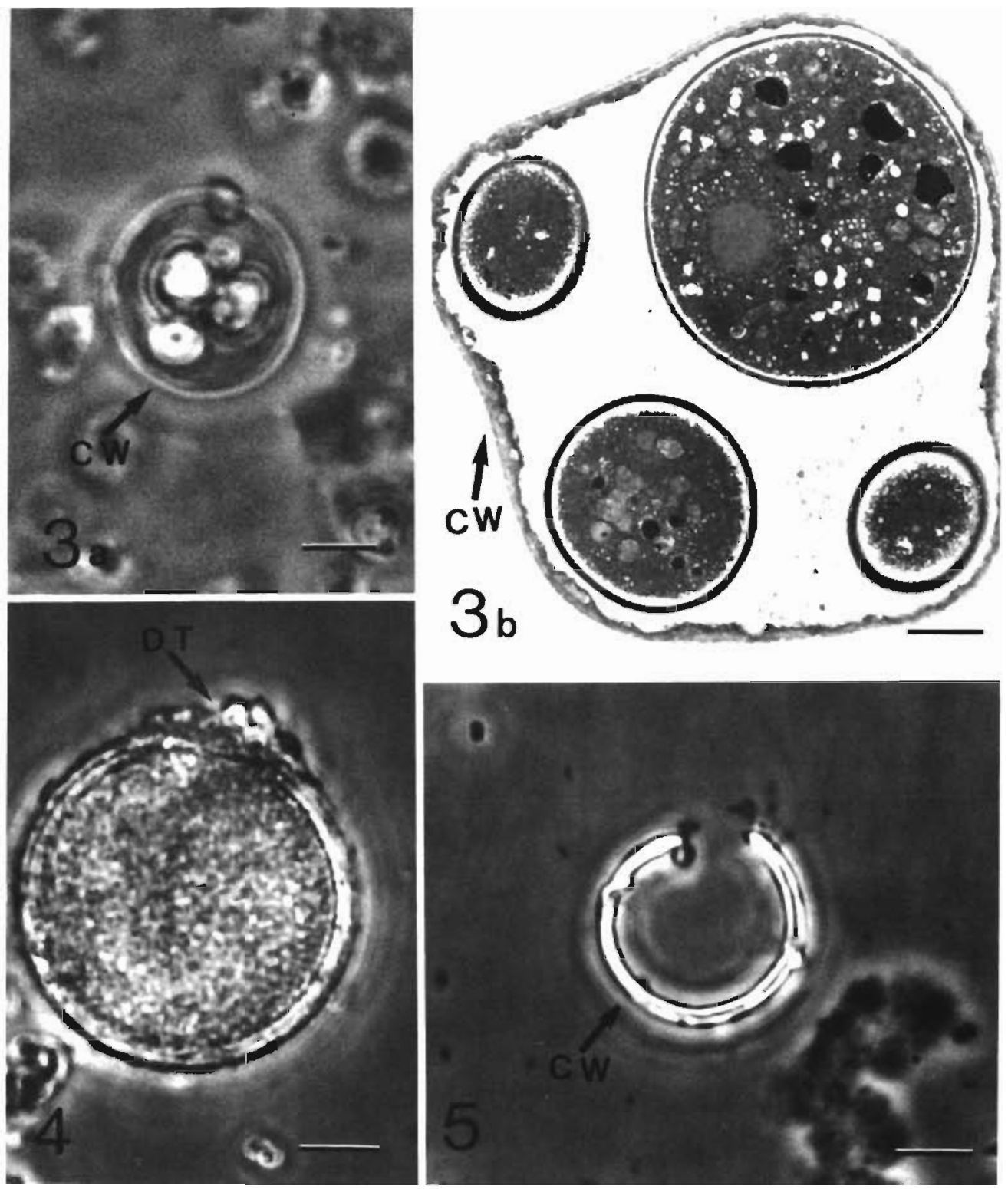

Figs. 3 to 5. Perkinsus karlssonj. Photomicrographs and electron micrographs. Fig. 3 (a) Zoosporangium undergoing cytokinesis giving rise to numerous cells. Scale bar $=42 \mu \mathrm{m}$. (b) Thin section of a similar zoosporangium which has begun to bipartition into separate cells contained within the same cell wall (CW). Scale bar $=5 \mu \mathrm{m}$. Fig. 4 Mature zoosporangium at the end of the zoosporulation phase beginning to develop a discharge tube (DT). Scale bar $=28 \mu \mathrm{m}$. Fig. 5 Empty zoosporangium following the release of zoospores. Scale bar $=42 \mu \mathrm{m}$

sensitive for detection of low-level infections and has the added advantage of being able to diagnose the parasite in live oysters.

Perkinsus karlssoni has not been seen to enlarge when incubated in FTM (McGladdery et al. 1991, and present study) unlike other named species of Perkinsus. The trophozoite and schizont stages within infected tissue, however, were observed to stain blueblack when treated with iodine solution, which is consistent with other species. McGladdery et al. (1991) suggested that the failure to enlarge may be due to the semi-natural conditions under which the scallops are cultivated or to some limitation of the culture medium. Whether $P$. karlssoni can be cultured in other media remains to be investigated.

In our laboratory, culture of infected tissue without FTM does not affect zoospore production and comparable numbers of zoospores were produced whether FTM was used or not. This finding suggests that FTM culture is not required for the diagnosis of Perkinsus 
karlssoni in bay scallops, nor has any effect on collection of trophozoites, schizonts, zoosporangia and zoospores. Indeed, culture of $P$. karlssoni in FTM proved to be an unnecessary, time-consuming step. Additionally, FTM is difficult to remove from parasite surfaces and can result in increased contamination by bacteria. The absence of bacteria and other contaminants is particularly important when using parasite material for in vitro culture and immunodiagnostic studies.

Digestion of either whole or macerated tissue with trypsin or pepsin did not enhance trophozoite recovery and subsequent development in seawater. In our laboratory, this technique did not result in a cleaner preparation as reported by Chu \& Greene (1989) for Perkinsus marinus, but generated a large amount of cell debris and recovered fewer numbers of parasites. The most efficient method for collection of zoosporangia and zoospores proved to be the maceration of scallop tissue followed by incubation in seawater at $26^{\circ} \mathrm{C}$ for $3 \mathrm{~d}$.

The in vitro sporulation of Perkinsus karlssoni zoosporangia and their development ultimately to zoospores seems to be similar to that described for $P$. marinus, $P$. atlanticus and $P$. olseni. We observed sporulation of $P$, karlssoni zoosporangia in SAS (salinity $27 \%$ incubated at $26^{\circ} \mathrm{C}$. Following repeated cell division, zoospores were released after $3 \mathrm{~d}$. This is in contrast to McGladdery et al. (1991) who observed zoospore production after 7 to $21 \mathrm{~d}$ in seawater maintained at 18 to $22^{\circ} \mathrm{C}$. The difference in length of time for zoospore production in $P$. karlssoni is probably a reflection of temperature-dependency. Temperaturedependence was identified in $P$. marinus and Chu \& Greene (1989) demonstrated temperatures of $28^{\circ} \mathrm{C}$ as favouring fast development of zoospores within 2 to $3 \mathrm{~d}$ in seawater. $P$. olseni was shown to develop zoospores in seawater maintained at $20^{\circ} \mathrm{C}$ after 8 d (Lester \& Davis 1981), and Azevedo (1989) obtained zoospores of P. atlanticus after 3 to $4 \mathrm{~d}$ in seawater at $28^{\circ} \mathrm{C}$. It should be emphasized however that prior to incubation in seawater, $P$. mannus, $P$. atlanticus and $P$. olseni were all cultured in FTM anywhere from 2 to $14 \mathrm{~d}$, whereas $P$. karlssoni was obtained directly from infected tissue with no prior FTM culture. Whether there is any effect of FTM culture on zoospore production in $P$. marinus, $P$. atlanticus or $P$. olseni is not known.

Purification of trophozoite and schizont stages of Perkinsus karlssoni was achieved by macerating bay scallop tissue, followed by filtration and centrifugation to produce an homogenate which was placed onto a Percoll gradient. Trophozoites and schizonts could be harvested at the 50 to $60 \%$ interface. The protocols for both trophozoite/schizont and zoospore collection appear to be qualitatively very effective, and relatively clean, viable material can be obtained. The ability to amass large quantities of purified parasitic material on a regular basis has enabled us to elaborate in vitro studies of purified developmental stages of P. karlssoni. This should enable further investigation of the mechanism of entry, survival and pathogenicity in the host organism. Additionally, the production of monoclonal antibodies to $P$. karlssoni is now in progress and will be used for immunodiagnosis of the disease in bay scallops.

Acknowledgements. We thank Mr R. Maloney for his technical assistance. This project was supported in part by funds awarded to R. J. Cawthorn from the Atlantic Fisheries Adjustments Programme (AFAP), the Atlantic Canada Opportunities Agency (ACOA), and the Natural Sciences and Engineering Research Council (NSERC).

\section{LITERATURE CITED}

Andrews, J. D. (1988). Epizootiology of the disease caused by the oyster pathogen Perkinsus marinus and its effect on the oyster industry. In: Fisher, W. S. (ed.) Disease processes in marine bivalve molluscs. Am. Fish. Soc. Spec. Publ. 18, p. 47-63

Azevedo, C. (1989). Fine structure of Perkinsus atlanticus n. sp. (Apicomplexa, Perkinsea) parasite of the clam Ruditapes decussatus from Portugal. J. Parasitol. 75(4): $627-635$

Azevedo, C. (1990). Fine structure of zoosporulation in Perkinsus atlanticus (Apicomplexa: Perkinsea). Parasitology 100: $351-358$

Craig, A. E. N., Powell, E. N., Fay, R. R., Brooks, J. M. (1989). Distribution of Perkinsus marinus in Gulf Coast oyster populations. Estuaries 12: 82-91

Choi, K.-S., Wilson, E. A., Lewis, D. H., Powell, E. N., Ray, S. M. (1989). The energetic cost of Perkinsus marinus parasitism in oysters: quantification of the thioglycollate method. J. Shellfish Res. 8 (1): 125-131

Chu, F.-L. E., Greene, K. H. (1989). Effect of temperature and salinity on in vitro culture of the oyster pathogen, Perkinsus marinus (Apicomplexa: Perkinsea). J. Invertebr. Pathol. 53: 260-268

Crosby, M. P., Roberts, C. F. (1990). Seasonal infection intensity cycle of the parasite Perkinsus marinus (and an absence of Haplosporidium spp.) in oysters from a South Carolina salt marsh. Dis. aquat. Org. 9: 149-155

Gauthier, J. D., Fisher, W. S. (1990). Hemolymph assay for diagnosis of Perkinsus marinus in oysters Crassostrea virginica (Gmelin, 1791). J. Shellfish Res. 9(2): 367-371

Goggin, C. L., Lester, R. J. G. (1987). Occurrence of Perkinsus species (Protozoa, Apicomplexa) in bivalves from the Great Barrier Reef. Dis. aquat. Org. 3: 113-117

Howard, D. W., Smith, C. S. (1983). Histological techniques for marine bivalve mollusks. NOAA Technical Memorandum NMFS-F/NEC-25

Karlsson, J. D. (1991). Parasites of the bay scallop, Argopecten irradians Lamarck (1819). In: Schumway, S. E., Sandifer, P. A. (eds.) An international compendium of scallop biology and culture. World Aquaculture Workshop no. 1 World Aquaculture Society, Baton Rouge, LA, p. 180-190

Lester, R. J. G., Davis, G. H. G. (1981). A new Perkinsus species (Apicomplexa, Perkinsea) from the Abalone Haliotis ruber. J. Invertebr. Pathol. 37: 181-187

Levine, N. D. (1978). Perkinsus gen. n. and other new taxa in 
the protozoan Phylum Apicomplexa. Parasitology 64 (3) 549

Mackin, J. G. (1951). Histopathology of infection of Crassostrea virginica (Gmelin) by Dermocystidium marinum Mackin, Owen and Collier. Bull. mar. Sci. Gulf Caribb. 1. $72-87$

Mackin, J. G., Owen, H. M., Collier, A. (1950). Preliminary note on the occurrence of a new protistan parasite, Dermocystidium marinum n. sp. in Crassostrea virgnnica (Gmelin). Science 111: 328-329

Mackin, J. G., Ray, S. M. (1966). The taxonomic relationships of Dermocystidium marinum Mackin, Owen and Collier. J. Invertebr. Pathol. 8: 544-545

McGladdery, S, E., Cawthorn, R. J., Bradford, B. C. (1991). Perkinsus karlssoni n. sp. (Apicomplexa) in bay scallops Argopecten irradians. Dis. aquat. Org. 10: 127-137

Perkins, F. O. (1988). Structure of protistan parasites found in

Responsible Subject Editor: A. K. Sparks, Seattle, USA bivalve molluscs. In: Fisher, W. S. (ed.) Disease processes in marine bivalve molluscs. Am. Fish. Soc. Spec. Publ. 18, p. $93-111$

Perkins, F. O., Menzel, R. W. (1966). Morphological and cultural studies, of a motile stage in the lifecycle of Dermocystidium marinum. Proc. natl Shellfish. Ass. 56: 23-30

Perkins, F. O., Menzel, R. W. (1967). Ultrastructure of sporulation in the oyster pathogen Dermocystidium marinum. J. Invertebr. Pathol 9: 205-229

Ray, S. M. (1966). A review of the culture method for detecting Dermocystidium marinum, with suggested modifications and precautions. Proc. natl Shellfish. Ass. 54: 55-69

Ray, S. M., Mackin, J. G., Boswell, J. L. (1953). Quantitative measurement of the effect on oysters of disease caused by Dermocystidium marinum. Bull. mar. Sci. Gulf Caribb. 3: $6-33$

Manuscript first received: July 1, 1992

Revised version accepted: January 11, 1993 